\title{
Reflections on Donald Capps'
}

\section{hermeneutical model of pastoral care}

\author{
Yolanda Dreyer \\ Department of Practical Theology \\ University of Pretoria
}

\begin{abstract}
This article reflects on the hermeneutical model of Donald Capps, William Harte Felmeth Professor of Pastoral Psychology at Princeton Theological Seminary. Capps points to a similarity between pastoral actions and texts, but regrets that often there is a better understanding of texts than of pastoral actions. The article illustrates Capps' conviction that theories of pastoral care lack methodologies for understanding what makes pastoral actions meaningful. He uses hermeneutics to make a contribution to the methodology of pastoral care. The article argues that viewing pastoral actions as texts and exploring the hermeneutical insights of Paul Ricoeur, will contribute to the understanding of the meaning of pastoral actions. Such a hermeneutical model uncovers how pastoral actions can be of world disclosing value to the individuals concerned. The article concludes by demonstrating how the notion of reframing in Capps' theory of pastoral care is based on the concept of the hermeneutical arc in Paul Ricoeur's philosophy.
\end{abstract}

\section{INTRODUCTION}

According to Don Browning (1991:36), practical theology should be based on "a critical reflection on the church's dialogue with Christian sources and other communities of experience and interpretation with the aim of guiding its action toward social and individual transformation." Such an approach requires that theories of pastoral care should be multi-faceted and interdisciplinary. Gerrit Immink (2003:178), concurring with Hans van der Ven (1990:117), describes the relationship between practical theology and the social sciences as a "critical correlation". Critical for him means that practical theology defines the domain of research from the perspective of a theological understanding of the praxis. A theological theory will come to a different reconstruction of reality than the social sciences. In a theological reconstruction religion is not seen primarily as a social or psychological phenomenon, but as faith praxis. 


\section{Donald Capps' hermeneutical model of pastoral care}

Theology reconstructs from the basis of theological theory (cf Schweitzer 1999:307-321; Immink 2003:182-183). Immink (2003:192) is hesitant to give social theory equal weight to theology when "geloof in praxis" is at stake. However, according to Den Dulk (2003:127), this caution is due to the fact that Immink regards the heritage of Immanuel Kant as the reason for secularisation and therefore not an acceptable dialogue partner for practical theology - a view Den Dulk (2003:127) does not share. Den Dulk and Don Browning both regard the social sciences as important for practical theology. According to Browning (1984:9) social sciences could, however, be "potentially destructive of human values unless they are guided in their practical application by tested religious and ethical traditions."

Practical theologians are therefore challenged to consider the philosophical theories behind scientific methods and the potential value of philosophy, psychology, sociology and anthropology for their theological discourse (see Browning 1996:81). In this regard the discussion of philosophers such as Schleiermacher, Dilthey, Gadamer and Ricoeur on the nature of hermeneutics has greatly influenced contemporary practical theology.

Donald Capps (1984), William Harte Felmeth Professor of Pastoral Psychology at Princeton Theological Seminary, explores how the discussion on hermeneutics can contribute to the practical theological area of pastoral care. Capps (1984:11) sees hermeneutics, the science of interpretation, as a method which could be valuable for understanding and evaluating pastoral actions (cf Gerkin 1983; Patton 1981). Capps appreciates the action-reflection model used in clinical pastoral education for presenting a method of reflection on pastoral actions, but points out the limitations of this model (Capps 1984:12):

- It is not clear about what "a pastoral action" is.

- It does not adequately clarify what "reflection" entails.

- There has not been sufficient systematic discussion on what elements such as theological, ethical, psychological and sociological insights are expected to contribute to the process of reflection.

- It does not elucidate the completion of the process of reflection. Questions that remain, are: When has one reflected enough? How does one know that sufficient insight into the pastoral action has been gained?

Principles of hermeneutics have been applied to social and political action and, according to Capps (1984) can also be utilised for a better understanding 
of pastoral actions. In his book, Biblical approaches to pastoral counselling ([1981] 2003:11), he says:

In surveying the literature on the use of the Bible in pastoral counselling, I have been struck by the fact that contemporary biblical studies have not informed these discussions to any appreciable degree. Some authors voice their support of modern methods of biblical research, while others castigate these methods, but the writings of biblical scholars are rarely cited by either camp. It is not difficult to understand why this is the case. Biblical studies have become the work of specialists, and their writings are often too technical or too narrowly focused to seem of value to pastoral counselling. A related problem is that biblical studies are a large enterprise, and it is not always easy to identify, out of this vast literature, the studies that promise to be most useful to pastoral counselling. The sheer scope and complexity of biblical scholarship tends to intimidate those who represent the practical theological disciplines. As a result, books and articles on the Bible's role in pastoral counselling are generally uninformed by relevant biblical scholarship. Once one decides to apply modern biblical studies to pastoral counselling, a difficult question is, How can one make such application?

In his book, Pastoral care and hermeneutics (1984), Capps finds Ricoeur's hermeneutical theory congenial to making the hermeneutical transition from texts to meaningful actions and applies this to pastoral actions.

Ricoeur's application of his interpretation theory can be seen in his many essays on biblical hermeneutics written since the 1970s (Ricoeur 1974a:7185; 1975:29-145; 1975-1976:14-33; 1977:1-37; 1979:215-227). He finds himself "on the borderline between philosophy and theology" (Lam 2004:101). Methodologically speaking, he does, however, separate philosophy and theology for the following reason: "The philosopher is not a preacher. He may listen to preaching, as I do; but insofar as he is a professional and responsible thinker, he remains a beginner, and his discourse always remains a preparatory discourse" (Ricoeur 1974b:441; cf Lam 2004:112). Vanhoozer (1990:224) puts it as follows: "Ricoeur does not proclaim the Gospel. Rather, like John the Baptist, Ricoeur serves the Gospel by baptizing our imaginations, philosophically preparing the way for the Word." This article aims to demonstrate how the notion of reframing in Donald Capps' theory of pastoral care is based on the concept of the hermeneutical arc in Paul Ricoeur's philosophy. 


\section{Donald Capps' hermeneutical model of pastoral care}

\section{HERMENEUTICS}

Similar to the work of the Dutch practical theologian, Gerben Heitink (2000:81) on pastoral care, the "counselling model" of Donald Capps, is hermeneutical. Heitink's $(2000: 5,80)$ point of departure is that of people as "living human documents", a concept coined by Anton Boisen (1946:38) and taken over by others in the field such as Charles Gerkin (1984), especially in his work, The living human document: Revisioning pastoral counseling in a hermeneutical mode. Heitink's hermeneutical approach to pastoral care has two components: bipolarity, based on the work of Hans-Georg Gadamer ([1960] 1994:291-300) and narrativity, based on the work of Paul Ricoeur. In Gadamer's hermeneutical circle the two poles of distance/alienation and closeness/availability come together in a dialectical way. Ricoeur ([1983] 1984:76-77) sees life as a story. This always means a coming together of different stories in communication, a fusion of horizons (see Houtepen 1997:201ff; Van der Ven 2000:94-95; Heitink 2000:74; cf Pieterse 2001:1112). Ricoeur elaborated on this "fusion of horizons" by working out the concept of the "hermeneutical arc". Capps' hermeneutical approach to pastoral care was developed from this hermeneutical concept.

Hermeneutics is the theoretical reflection on communication. If language is to be meaningful, it has to communicate effectively. Though the spoken or written word is not the only forms of communication (signs, symbols, gestures, attitudes, etc also communicate), they probably are the most widely used forms of communication. The spoken or written word should not only be heard or read, but also understood.

Hermeneutics is about understanding language by means of language. The verb hermeneuo can be found in biblical and extra-biblical Greek, meaning interpret or explain, and translate. Capps (2001:143-144) puts it as follows:

The word interpret means "to explain the meaning of or make understandable", "to translate", "to construe" (as in interpreting someone's silence as contempt), or "to bring out the meaning of," especially in the sense of offering one's own conception of a work of art, whether in performance or criticism. The sense of interpret that is perhaps most central for our purposes is "to bring out the meaning of," though the other meanings may also hover in the background. Sometimes the minister, as interpreter, does need to explain or make understandable or to translate into another form of discourse, or to construe the meaning of a behavior whose meaning may not be obvious or explicit. The central meaning of interpret for our purposes here, however, is "to bring out the meaning of," a definition implying that the "meaning" is already there in what the other person (or persons) is saying, but that it needs to be drawn out or made more 
explicit. The interpreter offers her own conception of what is being presented to her, but this is not a preconception that she formed before listening to the other person; it is a conception that is drawn from what is being said - or presented - to her.

In other words, hermeneutics encompasses the conditions for, principles of and execution of the process of understanding. Traditionally hermeneutics was seen as the theory of exegesis. This statement is no longer accepted on face-value (Van Aarde). Hermeneutics no longer constitutes "the rules" for exegesis. Rather it indicates the basic conditions for and principles of the process of understanding. The same hermeneutical principles are valid for all language usage. There is no separate set of principles for biblical and for other literature. In biblical hermeneutics the only difference is the nature of the literature and the context in which hermeneutics is being practised. Theological hermeneutics is directed toward the Bible as a collection of documents which appeals to the reader to respond with faith. The Christian theologian is engaged with this text in a different way than with other texts since understanding this text has implications for his or her entire existence, including mind and actions. Ricoeur (1982:78) puts it as follows: "Because there is revelation, because there is this seemingly nonhermeneutical moment of sameness between Absolute and immediacy, an infinite process of mediation is launched" (Ricoeur 1982:78).

Mediation presupposes difference and contrast which are overcome by means of sameness in the hermeneutical process - whether an immediacy between God and human beings in terms of theological reconciliation, or whether between contrasting dialogue partners in terms of literary/oral communication. A similar dynamics can be seen in the definition Jim Poling (1991:187; cf Capps 1993:100-101) gives of practical theology:

\begin{abstract}
Practical theology is theological interpretation of the unheard voices of personal and community life for the purpose of continual transformation of faith in the true God of love and power toward renewed ministry practice ... Reflection begins with the presence of differences and otherness in experience. Difference provokes thought. When persons or communities become aware of some desire that contrasts with identity, the potential contradiction requires reflection .... Without difference and contrast, there can be no selfconscious experience.
\end{abstract}

Awareness of "self-conscious experience" represents a hermeneutical shift from modernity to postmodernity. Modernity has brought about a shift in the meaning of biblical traditions and values. The binding and compulsory character of the witness of the Bible has disappeared to a large extent. People have become 


\section{Donald Capps' hermeneutical model of pastoral care}

increasingly aware of how the world-view represented in the Bible and from which basis the biblical message was communicated, differs from that of the people who today attempt to communicate that message clearly and effectively. It is easier to understand what the text communicated to the original audience than to find the meaning of the text for the present-day audience in their very different context. The text should therefore be "translated" (über-setzt) for the people of today. This is the hermeneutical task of theologians.

Hermeneutics forms the heart of the theological enterprise and is therefore interdisciplinary by nature. All theology, also practical theology, also pastoral care, is a hermeneutical activity since it is about how one should understand and how one should communicate in order for the recipients to best understand what is being communicated.

\section{DONALD CAPPS' UNDERSTANDING OF RICOEUR FOR THE THEORY OF PASTORAL CARE}

In order to understand a text, a method and principles for interpretation are needed. One hermeneutical method is to focus on the intention of the author in order to understand the text. Ricoeur (1976, 1978, 1980; cf Reagan 1978; Capps 1984:16-17) rather sees the text as an independent entity with multiple meanings. A possible meaning is what he calls "ostensive referential meaning" indicating the meaning of the text in the mind of the author as intended for the situation for which it was originally written. When the mind of the author and the original context are no longer available, it does not mean that the text has no meaning for subsequent situations. The original readers may have a slight advantage over subsequent readers in that they are closer in time to the text, which has implications on personal, social and historical levels. However, they do not have an advantage as far as the text itself is concerned. Capps (1984:18) makes it clear that in both the case of the original readers and later readers there is a distance between the readers and the text, which calls for interpretation.

All readers have the task of trying to understand the meaning of the text. According to Ricoeur the process is reciprocal. Not only do readers interpret the text, but the text also interprets the reader (see Capps 1984:19). The text "discloses a world" into which the reader is drawn or refuses to be drawn: ".. the world is the ensemble of references opened up by the text". This world of meaning offers "possible modes of being as symbolic dimensions of our being-in-the-world" (Ricoeur 1971:536). For Capps (1984:21) the idea that "the text interprets us by lighting up our own situation and 'enlarging' it into a world" is significant for pastoral care, because then the text frees us "from the visibility and limitation of situations by opening up a 
world for us, that is, new dimensions of our being-in-the-world" (Ricoeur 1971:536). This corresponds with the aim of pastoral care, which is to help people to enlarge their world in order to see beyond the limitations of their immediate situation.

The genre or form of the texts impacts on the way in which the text opens up the world. Different forms have different disclosive possibilities (cf Ricoeur 1980:73-118). The term genre refers to the generic characteristics a specific literary form has in common with other literary expressions. By means of these characteristics literary types can be distinguished (see Van Aarde [2005]). Poetry differs from prose, for example. In the New Testament the genre of "gospel" has different characteristics from a letter. The distinct characteristics of a letter over against a gospel necessitates a different approach to a letter than to a gospel. William Doty (1972:430) explains it as follows: "That genre must stand at least partly to indicate something beyond form, I take to be self-evident. Meaning, a common way to designate this additional factor, is genre-bound ... since generic expression must rank among the most important signal-systems used by the author."

Human actions also manifest in different forms. So do the actions of pastoral care. In al cases the forms of the actions make possible different kinds of world-disclosures. The genre of a specific pastoral action will disclose a certain understanding of how God is revealed in the lives of human beings (see Capps 1984:21-24; cf Capps 2003:12-14). In his book, Pastoral counselling \& preaching: A quest for an integrated ministry (1980:121-130), Capps distinguishes three "Biblical models of pastoral counselling" in accordance with genres found in the Bible: the psalmic, the proverbic, and the parabolic.

The way in which the text opens up the world, is through language. The polysemic characteristic of language enables it to provide ostensive meaning as well as meanings that disclose a world. Metaphor has a similar capacity to make ostensive references and to disclose a world - the latter building on the former. Metaphorical thinking can therefore assist in providing a model for the understanding of life and what happens in the world of human action (Capps 1984:24-25). According to Ricoeur (1981a:228-247) explanation by means of metaphor shows how explanation in hermeneutics in general works. Dan Stiver (2001:111) indicates that "[f]urther support for the role of metaphor in ordinary language comes from George Lakoff and Mark Johnson [1980] in Metaphors we live by. They argue that everyday language is interlaced with metaphors and that we commonally think in terms of metaphors." He also points out that Ricoeur's reflection on metaphor $(1972,1975)$ naturally led to his understanding of the nature of narrative. "Specifically, in light of the 


\section{Donald Capps' hermeneutical model of pastoral care}

hermeneutical arc that he was constructing in the 1970s, he pictured the intricate relationships between it, metaphor and narrative, in the following way" (Stiver 2001:113):

From one point of view, the understanding of metaphor can serve as a guide to the understanding of longer texts, such as a literary work. The point of view is that of explanation; it concerns only that aspect of meaning which we called the "sense," that is, the imminent pattern of discourse. From another point of view, the understanding of a work taken as a whole gives the key to metaphor. The other point of view is that of interpretation proper; it develops the aspect of meaning which we called "reference," that is, the intentional orientation towards a world and the reflexive orientation towards a self. So if we apply explanation to "sense," as the imminent pattern of the work, then we can reserve interpretation for the sort of inquiry concerned with the power of a work to project a world of its own and to set in motion the hermeneutical circle, which encompasses in its spiral both the apprehension of projected worlds and the advance of self-understanding in the presence of these new worlds. Our working hypothesis thus invites us to proceed from metaphor to text at the level of "sense" and the explanation of "sense," then from text to metaphor at the level of the reference of the work to a world and to a self, that is, at the level of interpretation proper.

(Ricoeur [1972] 1981:171)

The enterprise of interpreting a text aims to come to an understanding of its world-disclosive meanings and to appropriate these meanings. A further aspect of the interpretation of a text is to explain its world-disclosive power. This rational action serves the purpose of making the process of interpretation less subjective. Explanation can be done by analysing the structure of the text. An analysis of metaphorical language reveals similarity and dissimilarity between two phenomena, in the words of Sally McFague (1982:13) "it is and it is not". For Capps (1984:28) with his specific interest in what Ricoeur's theory can contribute to pastoral care, "structural analysis of the language system of metaphor is vitally important to our understanding of metaphor. Without it, we risk collapsing the distance between human situations ... and the sphere of God's activity".

The structural analysis of language alone does not disclose the text's meaning, but it keeps interpretation from being only intuitive and arbitrary. Capps' (1984:28) understanding of Ricoeur's view is "that a text's meanings are communicated through structures of thought, and these are crucial to understanding the world disclosed by the text". Because not only texts, but 
also human actions have systems of meaning, it is important for these meaning systems to be analysed in order to be understood, especially because the meaning systems of human actions are seldom self-evident (Capps 1984:29).

The critical distance achieved by rational enterprises such as analysing the language system of the text and identifying the structure of the text's system of meaning, ensures that the reading does not remain only naïve and subjective. Though on the one hand it might be a pity for the reader to lose the experience of a naïve, intuitive reading of the text, on the other hand critical distance contributes to the text having a world-disclosive effect on the reader. At the far end of the scale of critical distance is the "hermeneutics of suspicion" where the reader approaches the text with a reservation (Ricoeur 1978:213-222). According to Marx (see Ricoeur 1991; cf Stiver 2001:150-175) texts are to be examined in order to expose their origins in "false consciousness", that is a distorted view of reality which permeates the cultural context of the author and therefore finds its way into the text. The idea is not to understand and appropriate the world-disclosures of the text, rather to expose them. Postmodern biblical critics (e g, Adam 1995:5, 11) call the exposure of false consciousness "demystification" (cf Capps 1984:31). Though this process may seem destructive, the intent is to recover true consciousness. According to Ricoeur (1974:148) destruction "is a moment in every new foundation. The 'destruction' of hidden worlds is a positive task". True consciousness is recovered "when what man says is equal to what man does, and when his work is truly equal to his being" (Ricoeur 1974b:148). In other words, Ricoeur utilises a hermeneutics of suspicion in order to unmask "false consciousness" in certain structures of the cultural text. At the same time a hermeneutics of affirmation seeks to find the possible meaning of the text which discloses an authentic possibility (Lam 2004:117-118; see Kearney 116-119; cf Stiver 2001:146). As Werner Jeanrond (1991:70-72) explains it, Ricoeur's hermeneutic is one of both suspicion and retrieval.

The initial possibility was ' $n$ positive one which gradually became corrupted by false consciousness. Both should, therefore, be taken into account in the process of interpretation. Ricoeur (1981b:97) puts it as follows: "First, I cannot conceive of a hermeneutics without a critical stage itself ... Second, the critical sciences are themselves hermeneutical, in the sense that besides tending to enlarge communication they presuppose that the distortions of which they speak are not natural events but processes of desymbolization. The distortions belong to the sphere of communicative action." The critical aspect safeguards against approaching faith only from a naïve position. If we are to be naïve, it must be a postcritical naïvité ("second 


\section{Donald Capps' hermeneutical model of pastoral care}

naïvitié") (Ricoeur 1967; cf Wallace 1990; Stiver 2001:69). Stiver (2001:64) puts it as follows: "With the help of his [Ricoeur's] hermeneutical arc, one more clearly sees how this is a move from a first understanding, through critical explanation, to a second, postcritical understanding." In this way Ricoeur (1991:xiv) gradually brought hermeneutics to praxis together: "Little by little, a dominant theme asserts itself in this enterprise of militant hermeneutics, namely the gradual reinscription of the theory of texts within the theory action."

Another method for exposing false consciousness is demythologisation. In the preface to the French translation of Rudolf Bultmann's work, Jesus, mythology and demythologization, Ricoeur (1974b:382; cf Lam 2004:125) explains the hermeneutical challenge for Christianity:

There has always been a hermeneutic problem in Christianity
because Christianity proceeds from a proclamation. It begins with a
fundamental preaching that maintains that in Jesus Christ the
kingdom has approached us in decisive fashion. But this
fundamental preaching, this word, comes to us through writings,
through the Scriptures, and these must constantly be restored as
the living word if the primitive word that witnessed to the
fundamental and founding event is to remain contemporary.

Hermeneutics in the context of Christianity deals on the one hand with the relation between Scripture and kerygma and on the other hand with the relation between the two Testaments. The kerygma and the New Testament represent a rereading of Hebrew Scriptures. This was a hermeneutical process. Paul took this a step further by interpreting the entire existence of the faithful in the light of the passion and resurrection of Christ. Lam (2004:126) describes this as follows: "In short, the mutual relation of the meaning of Christ and the meaning of existence sets up a hermeneutic circle for the hearers of the Word of God." A third important hermeneutical relation is that of Scripture and human beings as the hearers, believers and interpreters of the text.

Ricoeur sees Bultmann's demythologisation not as "the abandonment of the mythic wrapping of the scripture" as is often the case, but rather as "the grasp of the kerygma ... through unveiling the cultural distance between the ancient time and ours. Our task is to understand the essence of meaning in the text ..." (Lam 2004:127). In this way demythologisation contributes to finding meanings in the text which are relevant and have world-disclosive potential for readers whose cultural contexts differ significantly from that of the 
initial readers. "To destroy and to interpret: these are the two faces of modern exegesis. For the Christian the destroying belongs to the act of listening. What we want is through this process of destruction to hear a more original and more originating word ... Its function is to open up, to inaugurate a possibility of existence" (Ricoeur 1968:251)

The text is approached with the conviction that its essential meanings represent true consciousness, but the cultural mythology by means of which these meanings are communicated obstruct the understanding of those essential meanings for readers from different cultural contexts. This keeps them from appropriating the world-disclosive meanings of the text. Another danger is that the world-disclosive meaning of the text could lose their power if they are absorbed into the natural cognitive systems of the other cultures. According to Ricoeur (1981c:139; see Stiver 2001:91; Capps 1984:31), this happened to the Old Testament at the time of the New Testament and to the New Testament in contemporary Christianity.

Methods for maintaining critical distance from the text are also useful for the hermeneutics of pastoral care. Both authors and interpreters are located in a specific temporal, psychological, cultural and social context. The 1980 s brought a new awareness of the implications of this fact. During this period interdisciplinary work in exegesis and theology became important. Many contributions followed which helped to explain the difference between the contexts of the original and modern-day readers (see Elliott 1986:1-33).

In his work, The shape of the past: Models and antiquity, Thomas Carney (1975:38) states that there is no choice as to whether or not models are to be used in the process of understanding. They will be. The choice rather lies in whether they are used consciously or not. To this could be added: the choice whether interpreters will be declaring their models at the onset of the interpretation process or not. Conceptual models not only have cognitive value. They also have a heuristic function. They serve to discover new insights, to test new viewpoints and to pose new questions (Elliott 1993:124-126). They encourage the researcher to look for patterns and correlations among the vast amount of available data. Of course appropriate models should be elected.

Explanation (theories, conceptual schemata and other analytical methods) has the aim to avoid the naivete of an intuitive interpretation. The method of demythologisation (separating what is central to the understanding of meaning from what is culturally misleading) is used to avoid naiveté of discrimination. With the method of demystification (exposing the false consciousness inherent to the text) the aim is to avoid the naivete of credulity - taking the text or pastoral action at face value without concern for the 


\section{Donald Capps' hermeneutical model of pastoral care}

cultural values that it reflects (Capps 1984:33-35). Demystification questions the presuppositions that certain things are "natural" and others "unnatural" and can therefore be discarded, seen as untrue or marginalized. Generally accepted values that some things have been legitimated by, for instance God or the Bible, are questioned. These "natural" and "legitimate" values are exposed by postmodernism as concealing underlying ideological motives. (Adam 1995:5, 11). Stiver (2001:140) emphasizes that Ricoeur wants to affirm critical tools in the field of biblical studies, but "he also desires to point beyond them to the rereading of a text ..."

Capps sees a similarity between pastoral actions and texts but regrets that there is often a better understanding of texts than of pastoral actions. He states it as follows: "[M]y own conviction is that we are very short on methodologies for understanding what makes pastoral actions meaningful" (Capps 1984:35). He then utilises hermeneutics to make a contribution to the methodology of pastoral care. Viewing pastoral actions as texts and borrowing hermeneutical methods, will contribute to the understanding of the meaning of pastoral actions, and it will uncover how pastoral actions are world-disclosive for the people concerned.

\section{A HERMENEUTICAL MODEL FOR PASTORAL CARE}

In his article "The model of the text: Meaningful action" Ricoeur (1981d) connects texts with meaningful actions in a way that opens up the possibility to understand human actions by means of a similar approach as that of understanding texts. Meaningful actions are those actions which are intentional and worth understanding. Written texts have more in common with meaningful actions than spoken words do. Some similarities are the following:

- Meaningful actions and written texts both have content which can be interpreted and their impact and influence reach beyond the moment.

- Both have consequences beyond the initial reading or action.

- Both open up a world beyond the initial context. Ricoeur (1981e:171) points to the world-discosive characteristic of written texts that speak of possible worlds and of possible ways of orienting oneself in those worlds. (see Stiver 2001:105-117). Meaningful action has a similar characteristic. In his work, "The model of the text: meaningful action considered as text", he shows how an important action develops meanings which can be actualised or fulfilled in situations other than the one in which this action occurred (see Capps 1984:37-40). 
- Both are open to reinterpretation. Written texts (not spoken words) and meaningful actions are not confined to the initial situation, but are accessible at a later stage and can therefore be reinterpreted by people other than the original role-players in different (new) contexts.

The comparison shows that texts and actions (therefore also pastoral actions) can be explained and understood by means of a similar hermeneutical process. Pastoral actions, too, have an impact beyond the moment, have consequences, open up a world and are open to reinterpretation.

Capps (1984:43) chooses a model of translation when transposing Ricoeur's hermeneutical principles from text to pastoral action. The limited effect of the author's intention on the Wirkungsgeschichte of the text translates to the pastoral care situation in that the conscious intentions of the pastor when performing the action carry limited weight. In attempting to understand the action, the focus should be on the action itself rather than on the intention of the agent.

The idea that the original readers have only a slight advantage (if any) over later readers, translates to pastoral action in that the pastoral action will impact not only the people originally involved, but also those who receive later reports of the action. As Capps (1984:44) puts it: "[A] pastoral action may be understood by anyone who has reasonable access to it." The world-disclosive property of texts translates to pastoral care in that a pastoral action has two types of meaning. I has meaning in the original situation. It also has a broader impact and significance - meaning beyond the original situation.

According to Ricoeur's hermeneutical theory for understanding the possible world-disclosures, the genre of form and the metaphorical content are important. Translated to pastoral action the first is about exploring what kind of world-disclosures are made possible by a specific pastoral form. According to Capps (1984:45), it is not sufficient simply to label the form, as for example "grief counselling". It is necessary to explore the form by working with the form, getting to know its possibilities by means of dynamic engagement with it (Capps 1984:45-47). An examination of form opens up a broad range of possibilities, whereas the examination of metaphorical content narrows down the possibilities to those that are appropriate.

In the hermeneutical process the focus is on the reader rather than on the author. The process is complete not when the author has completed the text, but when the reader has understood the meanings of the text. Translated to pastoral action the focus is not on the pastor initiating the action, but on when the action has been understood, in other words when the worlddisclosures of the action have been appropriated. This personal appropriation 


\section{Donald Capps' hermeneutical model of pastoral care}

does not necessarily happen directly at the time of the pastoral action. It may happen only much later. The appropriation is not restricted to the pastor or the people directly involved. The effect may be felt much wider. This perspective could have wide-spread implications: "Because appropriation of a text means orienting oneself to its world-disclosures, it may well result in a new approach to ministry" (Capps 1984:48). A reorientation of lives will be an indication that appropriation has taken place. Pastorally speaking it could be seen in perceptual, behavioural, cognitive and emotional changes. There could be changes in values, commitments, goals and convictions. Change confirms the hermeneutical insight that people do not only interpret texts or actions but are in turn interpreted by them.

When the disclosiveness of a pastoral action is investigated, the focus will especially be on what the metaphorical content reveals of the person's self-awareness. For Capps (1984:48) "to be interpreted means an increase in self-awareness". Self-awareness has religious significance and is therefore a key aspect in pastoral care which has a growth in self-awareness as one of its goals. The developmental psychologist Erik Erikson (1968:220) calls a sense of self "nothing less than the verbal assurance according to which I feel that I am the center of awareness in a universe of experience in which I have a coherent identity ... The counterplayer of the 'l' therefore can be, strictly speaking, only the deity who ... is Himself endowed with an eternal numinousness."

As texts have plot structure or internal dynamics, so do pastoral actions. Three movements are necessary for the understanding of pastoral actions (Capps 1984:49):

- $\quad$ identifying the basic dynamic of the pastoral action;

- $\quad$ making a diagnostic assessment of the action;

- determining whether and in what ways the action is disclosive.

The first two movements have long been part of pastoral care. The hermeneutical model adds a third: the world-disclosive effect of a meaningful pastoral action. Reflection is not complete until this aspect has been attended to, "since this is the ultimate purpose of the pastoral action" (Capps 1984:51).

Ricoeur (1981d:216; 1981f:153) points out the need for methods for exploring the language and meaning systems of the text. In his search for conceptual models for the interpretation of pastoral actions, Capps (1984:51) makes use of E D Hirsch's (1976:17-35) discussion of four approaches to understanding a text. They are the following: 


\section{- Intuitionism}

Hirsch (1976:10) sees the reader's understanding of a text as intuitive "because even though it is mediated at first by words, it is not constrained, in the end, by their form." Ricoeur (1981c:137), on the other hand, emphasises that form (genre) has a decisive effect on the disclosive possibilities of a text.

\section{- Positivism}

This position maintains that a text "has" a meaning, in other words that there is a direct correlation between the language system and "the" meaning. Hirsch (1976:25), however, points out that one language system can have multiple meanings. Further measures need to be taken in order to arrive at an understanding of the meanings of a text.

\section{- Perspectivism}

According to this approach different readers will interpret the same text in different ways because of their own subjective stance. This must, however, not be enforced in a dogmatic way. According to Ricoeur (1981e:175), one is not condemned "to oscilation between dogmatism and scepticism." Stiver (2001:94) explains Ricoeur's (1981e:176) view on perspectivism as follows: 'Ricoeur thus looks at a text in terms of a 'principle of plenitude,' which he defines oracularly: 'A text means all that it can mean.' He therefore attempts to stake out a middle ground between the extremes of tyranny and anarchy." The text does have a "self-identity" which can still be perceived, though it may be viewed from different angles.

\section{- Schematism}

Hirsch's (1976:32) preferred approach is the idea that the interpretation of texts "follows a general pattern which governs our coming to cognitive terms with our world". Texts are encountered with a certain pre-understanding which he calls "correctable" schemata: Such a "schema sets up a range of predictions or expectations, which if fulfilled confirms the schema, but if not fulfilled causes us to revise it" (Hirsch 1976:32). Stiver (2001:99) considers this insight, also emphasised by Ricoeur's hermeneutical model, as that it "opens up the door for treatment not only of religious texts but of religious experiences and actions. Theology can be considered as an aspect of the critical moment in the interpretation of texts but also in the interpretation of religious action."

In the same vein Capps regards all four of these approaches, intuitionism, positivism, perspectivism, and schematism, as significant for pastoral care. The intuitive approach would champion a pastoral care of "presence" with little 


\section{Donald Capps' hermeneutical model of pastoral care}

regard for the form of the pastoral action. Capps (1984:54) points out that, according to the hermeneutical model for pastoral care, the form has implications for the world-disclosive possibilities of a pastoral action. Form can therefore not be disregarded. He also warns against applying the methods of one form to others or choosing a favourite form and tailoring all pastoral actions to that form.

The positivistic approach would take the action itself seriously. The danger here is to limit "the meaning" of the action to the facts of "what happened" instead of being open to multiple meaning of pastoral actions and their world-disclosive possibilities of "what may be happening" (Capps 1984:55). The perspectivist approach is useful for the initial understanding of a pastoral action. It is not sufficient, however, since it does not take into account the "self-identity" or inherent meaning which will become evident regardless from which perspective it is viewed. "[T]he action and not the interpreter is the ultimate source of its multiple meanings. If these multiple meanings are located in the action, then they are objectively there and not merely a function of the perspectives of the interpreters" (Capps 1984:56). The schematist approach goes beyond the limitations of the perspectivist approach. The perspectives of the interpreter are taken seriously, but do not fully determine the understanding of meanings. The perspective or schemata are adjusted and corrected when necessary. This reduces the relativism of the perspectivist approach. Capps (1984:57) puts it as follows: "While the text is always open to reinterpretation, there are limits to what it can mean." Conceptual schemata enable one to access the systems of meaning of a text. The schemata do not represent rigid patterns of understanding to be imposed on the text. Schemata are to be corrected and adjusted in interaction with the text. Capps (1984:61-65) hold the same to be true for finding the deeper meanings of pastoral actions and suggests the following criteria for useful conceptual schemata:

- $\quad$ They should assist in maintaining a critical distance from the pastoral action. This helps with the transition from initiator of the action to interpreter of the action.

- $\quad$ They should provide a means for helping to understanding the action.

- $\quad$ They should help to identify the world-disclosive possibilities of the action. They assist in the transition from the question "what happened?" to the question "what may be happening?"

- $\quad$ They should be conducive to the evaluation and assessment of the world-disclosive effects of the action. 
- They should help the interpreter to find the place of the pastoral action in the bigger picture of the pastor's ministry and self-understanding.

\section{FROM THE CONCEPT OF THE HERMENEUTICAL ARC TO THE CONSEPT OF REFRAMING}

Ricoeur (1984:52-87; 1985:157-179; cf Stam \& Egger 1997:69-85) sees every individual as a story written in time. People are always writing and revising their stories in light of their experiences. The attempts of the conscious to interpret are not free creations, but are the rewriting of a story consisting of many chapters. Dan Stiver (2001:39) describes it as follows: "We always experience the present influenced by our memories of the past and our projections into the future. We experience the world in terms of retentions and potentions, all part of our intentions."

Hans-Georg Gadamer and Paul Ricoeur take it further. In reading the text a fusion of horizons happens, according to Gadamer (1989:302-307; cf Stiver 2001:45-50). These are the horizon of one's own preconceptions, culture and traditions and that of the text. The other horizon is understood through one's own. Every individual has been formed by his or her tradition which cannot be escaped. Traditions provide one's preconceptions, and preconceptions form a frame of reference which makes understanding possible.

Ricoeur's idea is related to that of Gadamer. He too, finds that people do not control interpretation, but "are interpreted", are played by the game. He explains this by means of the concept of the "hermeneutical arc". The process consists of three movements, namely mimesis ${ }^{1}$ (prefiguration), mimesis ${ }^{2}$ (configuration) and mimesis $^{3}$ (refiguration). Mimesis ${ }^{1}$ is a kind of initial competence by means of which one approaches a story. The questions "what", "why", "who", "how", "with whom" and "against whom" are asked. These questions are asked from a practical understanding that the reader already has. In Gadamer's language this is the preconceptions necessary for understanding. The reader expects that the characters have certain reasons for doing what they do.

Mimesis $^{2}$ opens up the realm of fiction where the idea of the story becomes important. Events are to be related to one another. The question is asked why they happen in a specific sequence. The end of the story can only have meaning in relation to the whole story. Mimesis ${ }^{1}$ is about the expectations of the reader. Mimesis ${ }^{2}$ becomes clear when the character's behaviour is "in character", as expected. The reasons for the actions can be 


\section{Donald Capps' hermeneutical model of pastoral care}

seen with hindsight. The story itself is nothing. The reader makes it happen by reading it.

Mimesis ${ }^{3}$ is where the world of the text and the world of the reader come together and the message of the text is appropriated in the "real world". It reaches beyond the story itself. If the story did not have this referential meaning, then the reader would not be able to fathom the deeper meaning of the text (cf Simms 2003:84-86). According to Simms (2003:86) mimesis ${ }^{2}$ is the most important phase of the model since it opens the possibility of fiction and mediates between mimesis ${ }^{1}$ en mimesis $^{3}$. Mimesis ${ }^{1}$ is the "preconceptions", or in Gadamer's language the own horizon with its ideas, culture and traditions with which the reader approaches the text. Mimesis ${ }^{3}$ is a new understanding of the world as a consequence of having read and understood the meaning of the text. Mimesis ${ }^{2}$ is the process between the two. In this phase all events are arranged in such a way as to form a story. The reader can understand the story because it is an imitation of the real world. The actions in the story are human actions. In a nutshell: prefiguration is configured in refiguration. The present is an anticipation of the future mediated by the memory of the past. Only if this happens, reframing can take place. In his book, Reframing: A new method in pastoral care (1990) Capps calls the third dimension "reframing".

In accordance with Ricoeur's hermeneutical model, Capps (1990) considers "reframing" in pastoral care analogous to the notion of mimesis ${ }^{3}$. The three dimensions essential to Capps' (1984:118) hermeneutical model of pastoral care are structure, process and focus. Structure is about pastoral self-understanding, the genre of pastoral action such as hospital visitation, grief counselling, crisis counselling and the like, and self-awareness. Under process he places pastoral orientation, the interpretive process and the disclosive event. Focus refers to intentionality, interpretation and evaluation.

Capps (1990:17) makes use of the work of psychologists Watzlawick, Weakland and Fisch (1974). In Change: Principles of problem formation and problem resolution they distinguish between "first order change" and "second order change". To "reframe" means to "change the conceptual and/or emotional setting or viewpoint in relation to which a situation is experienced and to place it in another frame which fits the 'facts' of the same concrete situation equally well or even better, and thereby changes its entire meaning" (Watzlawick et al 1974:95). First order change is superficial and has no effect on the system itself. Second order change alters the system. A totally new situation comes about. With first order change many things in the person can change but the situation remains the same. With second order change everything changes because the system is no longer the same. The practical 
manifestation of second order change is often not logical, but paradoxical (see Watzlawick et al 1974:10-12).

Accepting such a paradox is, however, not always easy.

Psychologically speaking people find easier ways to try and deal with problems. One such way is simplification such as total denial (and attacking those who do see what the problem is) or the willingness to recognise that there is a problem, but insisting on finding a simple (easy) solution while no such solution exists. Another way is utopianism, such as trying to reach an unattainable goal (introjective utopianism) or believing that one has found "the truth" and trying to covert the world to one's way of thinking (projective utopianism). The symptoms of the first form are depression, a nihilistic worldview, alienation and suicidal tendencies. The problem with the first form is being out of touch with the reality of one's own abilities. The problem with the second is being out of touch with the world. The symptoms of this form are a paranoid self-justification and the illusion of originality - possessing a solution to the world's problems that has never been thought of before. The two forms of utopianism have one thing in common: the idea that perfect happiness is attainable and that insurmountable problems have a solution, have both been proven by human experience to be unrealistic.

A third way of dealing with troubles in an ineffective way, is by means of paradox. The action is undertaken on the wrong level. First order change is attempted where second order change is needed, or the other way round. Where this is attempted, the person becomes trapped in first order change (cf Watzlawick et al 1974:31-61). Only when one acknowledges that the attempted solutions present a paradox, then a possibility for second order change has been created.

This methodology of pastoral care flows directly from Capps' exploration of the hermeneutics of biblical texts. His hermeneutical model uncovers how pastoral actions can be of world-disclosive value for the individual concerned. Capps' (1984:121) aim is to address the limitation of the action-reflection model, namely that it does not provide for the necessary interpretation of pastoral actions. On why it is necessary: "For pastoral actions are appropriated through interpretation and therefore those that are not interpreted are like a seed that 'fell on the rock; and as it grew up, it withered away, because it had not moisture' (Lk 8:6)" (Capps 1984:121).

\section{Works consulted}

Adam, A K M 1995. What is postmodern biblical criticism? Minneapolis, MN: Fortress.

Browning, D 1984. Series Foreword, in Capps, D, Pastoral care and hermeneutics. Philadelphia, PA: Fortress. (Theology and Pastoral Care.) 


\section{Donald Capps' hermeneutical model of pastoral care}

Browning, D 1991. A fundamental practical theology: Descriptive and strategic proposals. Minneapolis, MN: Fortress.

Capps, D 1980. Pastoral counselling and preaching: A quest for an integrated ministry. Eugene, OR: Wipf \& Stock Publishers.

Capps, D [1981] 2003. Biblical approaches to pastoral counselling. Eugene, OR: Wipf and Stock Publishers.

Capps, D 1984. Pastoral care and hermeneutics. Philadelphia, PA: Fortress. (Theology and Pastoral Care.)

Capps, D 1990. Reframing: A new method in pastoral care. Minneapolis MN: Fortress.

Capps, D 1993. The poet's gift: Toward the renewal of pastoral care. Louisville, KY: Westminster.

Capps, D 2001. Giving counsel: A minister's guidebook. St Louis, MS: Chalice.

Carney, T F 1975. The shape of the past: Models and antiquity. Lawrence, KS: Coronado Press.

Den Dulk, M 2003. Positiekeuze van een praktisch theoloog. Theologia Reformata 46(2), 122-129.

Doty, W G 1972. The concept of genre in literary analysis, in McGouchy, L C (ed), SBL Proceedings, Vol 2: Book of Seminar Papers, 413-448. Philadelphia, PA:Fortress.

Elliott, J H 1986. Social-scientific criticism of the New Testament: More on methods and models. Semeia 35, 1-33.

Elliott, J H 1993. What is social-scientific criticism? Minneapolis, MN: Fortress Press.

Erikson, E 1968. Identity, youth and crisis. New York: W W Norton.

Gadamer, H-G 1989. Truth and method, tr by J Weinsheimer and G Marshall, 2nd rev ed. New York: Continuum.

Gerkin, C V 1983. The living human document: Re-visioning pastoral counselling in a hermeneutical mode. Nashville, TN: Abingdon.

Heitink, G [1998] 2000. Pastorale zorg: Theologie, differentiatie, praktijk. 2e druk. Kampen: Kok. (Handboek Praktische Theologie.)

Hirsch, E D 1976. Old and new in hermeneutics, in The Aims of Interpretation, 17-35. Chicago: University of Chicago Press.

Houtepen, A 1997. God, een open vraag: Theologische perspectiven in een cultuur van agnosme. Zoetermeer: Meinema.

Immink, F G 2003. In God geloven: Een praktisch-theologische reconstructie. Zoetermeer: Meinema.

Jeanrond, W 1991. Theological hermeneutics: Development and significance. New York: Crossroads.

Kearney, R 1986. Religion and ideology: Paul Ricoeur's hermeneutic conflict. The Irish Theological Quarterly 52.

Lakoff, G \& Johnson, M 1980. Metaphors we live by. Chicago, II: University of Chicago Press.

Lam, J T 2004. Toward a theological hermeneutic of testimony: Paul Ricoeur on witness to the kerygma. Jian Dåo, A Journal of Bible \& Theology, 22, 99-135.

McFague, S 1982. Metaphorical theology. Philadelphia, PA: Fortress.

Patton, J 1981. Clinical hermeneutics: Soft focus in pastoral counseling and theology. Journal of Pastoral Care 35, 157-168.

Perrin, N 1976. Jesus and the language of the kingdom. Philadelphia, PA: Fortress. 
Pieterse, H C J 2001. Preaching in the context of poverty. Pretoria: University of Pretoria.

Poling, J N 1991. The abuse of power: A theological problem. Nashville, TN: Abingdon Press.

Reagan, C E \& Stewart, D (eds) 1978. The philosophy of Paul Ricoeur: An anthology of his works. Boston, MA:Beacon Press.

Ricoeur, P 1967. The symbolism of evil, tr by E Buchanan. New York: Harper \& Row. (Religious Perspectives 17.)

Ricoeur, P 1968. Tasks of ecclesial community in the modern world, in Renewal of religious structures, ed by L K Shook. New York: Herder and Herder.

Ricoeur, P [1972] 1981. Metaphor and the central problem of hermeneutics, in Thompson, J B (ed), Hermeneutics and the human sciences: Essays on language, action and interpretation, 165-181. Cambridge: Cambridge University Press.

Ricoeur, P 1974. Philosophy and religious language. Journal of Religion 54, 71-85.

Ricoeur, P 1974b. The conflict of interpretations: Essays in hermeneutics, edited by $D$ Ihde. Evanston, III: Northwestern University Press.

Ricoeur, P 1975. Biblical hermeneutics. Semeia 4, 29-145.

Ricoeur, P 1975-1976. Philosophical hermeneutics and theological hermeneutics. Studies in Religion 5, 14-33.

Ricoeur, P 1976. Interpretation theory: Discourse and the surplus of meaning. Fort Worth, TX: Christian University Press.

Ricoeur, P 1977. Toward a hermeneutic of the idea of revelation. Harvard Theological Review 70, 1-37.

Ricoeur, P 1978. The critique of religion, translated by R Bradley DeFord, in Reagan, C E \& Stewart, D (eds), The philosophy of Paul Ricoeur: An anthology of his works, 213-222. Boston, MA:Beacon Press.

Ricoeur, P 1979. Naming God. Union Seminary Quarterly Review 34, 215-227.

Ricoeur, P 1980. Essays on biblical interpretation, ed by L S Mudge. Philadelphia, PA: Fortress.

Ricoeur, P 1981a. The metaphorical process as cognition, imagination, and feeling, in Johnson, M (ed), Philosophical perspectives on metaphor, 228-247. Minneapolis, MN: University of Minnesota Press.

Ricoeur, P 1981b. Hermeneutics and the critique of ideology, in Thompson, J B (ed), Hermeneutics and the human sciences: Essays on language, action, and interpretation. Cambridge: Cambridge University Press.

Ricoeur, P 1981c. The hermeneutical function of distanciation, in Thompson, J B (ed), Hermeneutics and the human sciences: Essays on language, action, and interpretation, 131-144. Cambridge: Cambridge University Press.

Ricoeur, P 1981d. The model of the text: Meaningful action considered as text, in Thompson, J B (ed), Hermeneutics and the human sciences: Essays on language, action and interpretation. Cambridge: Cambridge University Press.

Ricoeur, P 1981e. Metaphor and the central problem of hermeneutics, in Thompson, J B (ed), Hermeneutics and the human sciences: Essays on language, action and interpretation. Cambridge: Cambridge University Press.

Ricoeur, P 1981f. What is a text? Explanation and understanding, in Thompson, J B (ed), Hermeneutics and the human sciences: Essays on language, action and interpretation. Cambridge: Cambridge University Press. 


\section{Donald Capps' hermeneutical model of pastoral care}

Ricoeur, P 1982. The status of Vorstellung in Hegel's philosophy of religion, in Rouner, L S (ed), Meaning, truth and God. Notre Dame, IN: University of Notre Dame Press.

Ricoeur, P 1984. Time and narrative, Vol 1, tr by K McLaughlin \& D Pellauer. Chicago, IL: University of Chicago Press.

Ricoeur, P 1985. Time and narrative, Vol 2, tr by K McLaughlin \& D Pellauer. Chicago, IL: University of Chicago Press.

Ricoeur, P 1991. From text to action: Essays in hermeneutics, II, tr by K Blamey \& J B Thompson. Evanston, IL: Northwestern University.

Schweitzer, F 1999. Practical theology, contemporary culture, and the social sciences - interdisciplinary relationships and the unity of practical theology as a discipline, in Schweitzer, F \& Van der Ven, J A (eds), Practical Theology International perspectives, 307-321. Frankfurt am Main/Berlin.

Stam, H J \& Egger, L 1997. Narration and life: On the possibilities of a narrative psychology, in Joy, M (ed), Paul Ricoeur and narrative: Context and contestation, 69-85. Calgary: University of Calgary Press.

Simms, K 2003. Paul Ricoeur. Londen: Routledge.

Stiver, D 2001. Theology after Ricoeur: New directions in hermeneutical theology. Louisville, KY: Westminster John Knox.

Van Aarde, A G 2004. Teologiese Hermeneutiek. OTW (BTh) 451 Studiehandleiding, Universiteit van Pretoria.

Van Aarde, A G [2005]. Narrative analysis, in Du Toit, A B (ed), Reading the New Testament: Hermeneutics, exegesis and methods. Grand Rapids, MI: Eerdmans. (HNT/GNT 3.) (Forthcoming.)

Van der Ven, J A 1990. Entwurf einer empirischen Theologie. Kampen: Kok.

Van der Ven, J A 2000. Pastoraal perspectief: Vorming tot reflektief pastoraat. Kampen: Kok. (Theologie \& Empirie.)

Vanhoozer, K J 1990. Biblical narrative in the philosophy of Paul Ricoeur. Cambridge: Cambridge University Press.

Wallace, M I 1990. The second naiveté: Barth, Ricoeur, and the New Yale Theology. Macon, GA: Mercer University Press. (Studies in American Biblical Hermeneutics.)

Watzlawick, P, Weakland, J \& Fisch, R 1974. Change: Principles of problem formation and problem resolution. New York: Norton. 